\title{
Kinect を用いたダンスの撮影装置
}

\author{
浜崎 有馬 ${ }^{a}$ 北園 優希 ${ }^{a}$ \\ a 北九州工業高等専門学校
}

\section{1.はじめに}

ダンスは，体一つあれば楽しめる身近な娛楽である。 感情表現のため, 神への祈りのため, もはや生活のため ともいえるほどに, 長い間受け入れられ, 親しまれてき た。その親しみは現代でも変わらない。

例えば，ダンスは言葉のいらない最もシンプルなコミ ユニケーション手段[1]として, コミュニケーション能力 向上や交流の機会の場とされていたり, 野球やバレーボ ールなどと並ぶスポーツとして大規模な大会が開かれた りしていることが挙げられる.

平成 20 年 3 月には中学校での武道・ダンス必修化[2] も行われていることからも, ダンスで伝わるものの重要 性を感じられる。

そんな年齢性別を問わないダンスにおいて，制作者の 存在は必須である。プロでも子供の発表会でも例外はな い.ダンスがより身近になった今，ダンスの創作も必然 的に身近になるはずである。ここで問題となるのが，創 作したダンスの保存と記録の方法である.

ダンスに限らず，創作物は形に残さないと意味をなさ ない。しかしダンスは一般的な創作物に比べ, 形として 残りにくく，「一度考えた振り付けを忘れる」「どんな動 きか自分から見えない」といった問題が生じるのである.

この問題の解決のため, RGB カメラを用いて, 振り付 けごとに動画を保存, 自由に組み合わせ再生できるアプ リケーションの開発を行うことにした。

これまでの研究により, ダンスを保存, 再生, 創作す る装置としての形は完成したが，ボタンによる撮影開始 の手順の煩わしさが問題となった。

よって今回は, 撮影開始の方法をボタンから, kinect のセンサーを用いたジェスチャーに変更することで，撮 影場所から動かずに撮影を行うことを目的とする.

\section{2. 開発環境}

Microsoft Visual Studio 2017 を開発環境として, Microsoft .NET Framework の一つである WPF(Windows Presentation Foundation)を用いて開発した。言語は c\#で ある。

Dance photography device using Kinect

Yuma Hamasaki ${ }^{\text {a }}$ Yuhki Kitazono ${ }^{a}$

aNational Institute of Technology, Kitakyushu College

\section{3. アプリ概要}

\section{1 アプリの構成}

開発アプリは，主にメインウィンドウと撮影ウィンド ウで構成されている。この二つのウィンドウを操作する ことで, 撮影・保存・読み取り・再生の一連の処理を行 う. その機能と大まかな処理の流れを図 1 に示す.

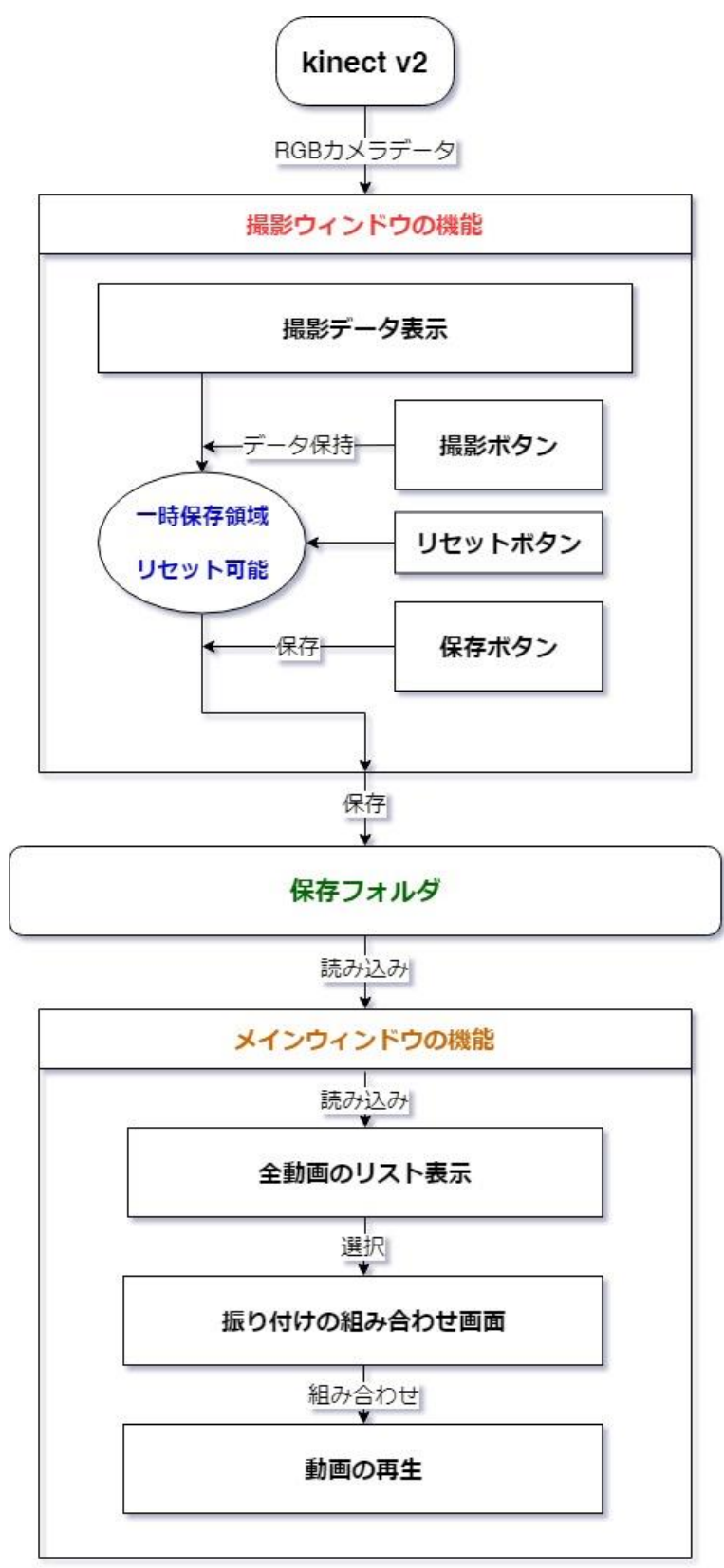

Fig.1.メインウィンドウ 


\section{2 基本機能}

ここまで挙げられた機能（撮影，保存，読み取り，再 生）は, このアプリの基本機能である. 撮影・保存機能 は撮影ウィンドウに実装して, 読み取り・再生機能はメ インウィンドウに実装した。

各ウィンドウで機能を分担することによって, 図 1 の ように分岐のない単純な処理の流れでアプリを構成する ことができたため, ウィンドウ単体の操作も非常に単純 なものになっている.

さらに，保存フォルダを挟んでいること以外は二つの ウィンドウ間につながりはないため, 一方のウィンドウ の動作が, もう一方のウィンドウの動作の妨げになるこ とはなく，独立した機能として扱うことができる．

以下に, 各ウィンドウの機能を説明する．ここに追加 機能を加えていくことで，アプリの完成を目指すことに なる。

(a) 撮影ウィンドウ

撮影ウィンドウがまず初めに行う処理は RGB カメラ データの取得である。撮影ボタンが押されてから，一定 時間ごとに一時保存領域（プログラムでいう配列，バッ ファ）に保存し，そのデータを保存すると判断した場合 のみ保存フォルダ (ストレージ) にデータを送る。撮影 開始，リセット，保存といった各判断は，ボタンによる 操作で行う仕組みである。このような動画の撮影と保存 までの処理を担うのが撮影ウィンドウの機能である.

(b) メインウィンドウ

撮影ウィンドウによって保存された振り付け動画を いくつか取り出し，組み合わせることで，新しいダンス を創作できるようにする，そのためには，保存されたす ベてのデータを読み取り管理する機能, 任意の振り付け を選択できる機能, 加えて選択した振り付けを組み合わ せるための機能が必要になるだろう。これらの機能を実 現し, 動画を再生できる状態まで導くのが, メインウィ ンドウの機能である.

\section{4. 追加機能}

\section{1 導入}

今回，追加したい機能は，撮影ウィンドウに実装され ている撮影ボタンの代わりに撮影開始の信号となりえる システムである。

本研究では, kinect センサーの骨格検出機能を用いて, 撮影ボタンを押す代わりに，腕を三回振ることで撮影を 始める機能を加えることにした．

\section{2 骨格検出}

Kinect v2 センサーは, 図 2 に示すように 25 か所の骨 格データを所得できる[3]. そのデータは全て XYZ の三 次元空間での座標である。本研究では, 腕の動きを検知 するために「右手」のデータを取得することにした。

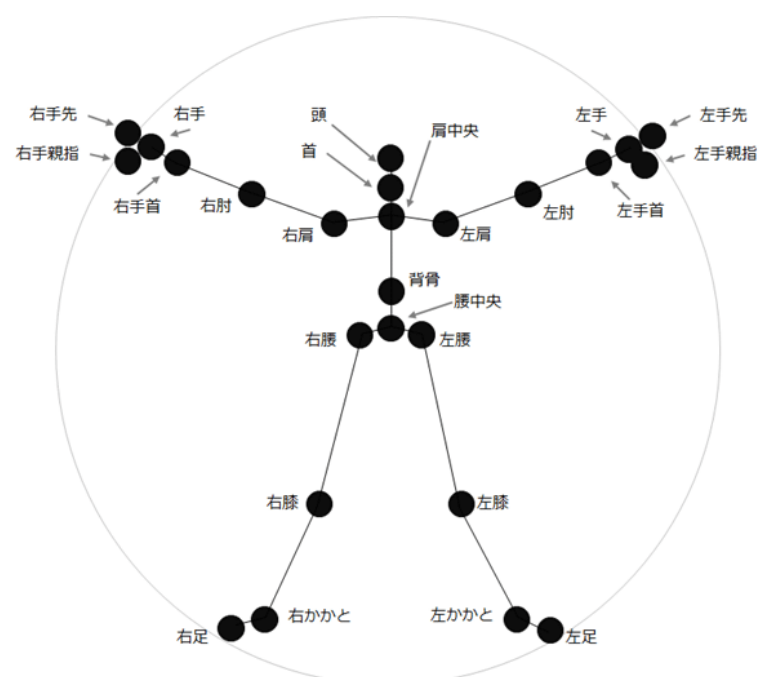

Fig.2. Kinect v2 による骨格検出

\section{3 撮影合図の実装方法}

実装方法は単純である。まずセンサーがデータを得る 度に，前回取得した位置情報との差をとり，これを速度 とする。このとき前回も同様に速度を得ているため，そ の速度の差をとることで加速度を得ることになる。

このとき加速度の $\mathrm{X}, \mathrm{Y}, \mathrm{Z}$ 方向の值の符号が，どれ か一つでも変わったとき，手を一回振ったと判断するこ とにした。

\section{4 動作確認}

腕を振る行為の検知を行うことが確認できた。しかしそ の精度には改善が必要である。

\section{5. 終わりに}

今回は，アプリに新しい撮影開始方法を追加すること で，撮影手順の改善を行った。このほかにもアプリの問 題となる要素は多く存在するため, 追加機能を加えるこ とで扱いやすさを改善していきたい.

\section{文献}

(1) $\mathrm{NOA}$ ダンスアカデミーHP：「ダンスとは」, https://www.noadance.com/aboutdance/

(2) 文部科学省「武道・ ダンス必修化」 http://www.mext.go.jp/a_menu/sports/jyujitsu/1330882.htm

（3）初音玲：「新型 Kinect の骨格データに関する新機能とは?」, https://www.buildinsider.net/small/kinect2dp/03 